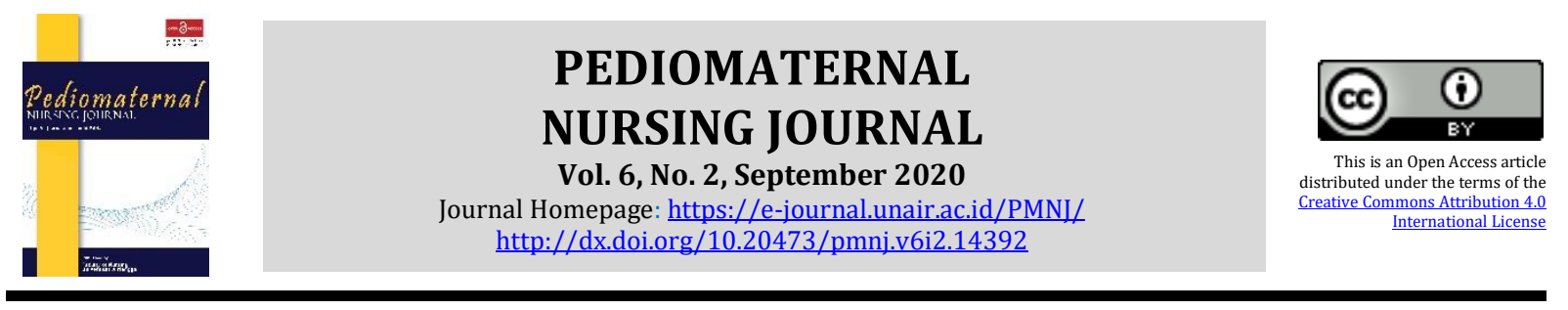

Original Research

\title{
Pain Self-management in Adolescent with Dysmenorrhea
}

\section{Cherlys Tin Lutfiandini' ${ }^{1}$, Tiyas Kusumaningrum², Ni Ketut Alit Armini2}

${ }^{1}$ Bachelor Student, Faculty of Nursing, Universitas Airlangga, Surabaya, Indonesia

${ }^{2}$ Faculty of Nursing, Universitas Airlangga, Surabaya, Indonesia

\section{ARTICLE HISTORY}

Received: May 15, 2020

Accepted: June 30, 2020

Published: July 1, 2020

\section{KEYWORDS}

pain self-management; selfefficacy; information support; decision making

\section{CORRESPONDING AUTHOR}

Ni Ketut Alit Armini nk.alita@fkp.unair.ac.id Faculty of Nursing, Universitas Airlangga, Surabaya, Indonesia

Cite this as:

\begin{abstract}
Introduction: Complaints that often occur are dysmenorrhea that is not harmful but can interfere with comfort and activity. An adolescent who know the proper management of dysmenorrhea can overcome it and have good pain management. The study aimed to analyze pain self-management in adolescents with dysmenorrhoea.
\end{abstract}

Methods: This study used correlational research with a cross-sectional approach. The population in this study were adolescent at Public Junior High School IV Lamongan. The samples were 129 respondents selected by simple random sampling. The inclusion criteria were an adolescent who analyzes dysmenorrhea. The exclusion criteria for this study were not in place due to illness or alpha. Data was collected using questionnaire selfefficacy, decision making, information support, and pain self-management that had been tested for validity and reliability-test statistics using the Spearman's rho test.

Results: The results of the study found a correlation between self-efficacy with pain self-management $(\mathrm{p}=0.004 ; \mathrm{r}=0.24)$, decision making with pain self-management $(p=0.003 ; r=0.26)$, information support with pain selfmanagement $(\mathrm{p}=0.003 ; \mathrm{r}=0.26)$.

Conclusion: Self-efficacy is a mediator to improve pain self-management optimally to improve quality of life. There are three factors in decision making for pain management in adolescents who experience dysmenorrhea is personal, social, and psychological. Adolescents who have initiatives in finding information about dysmenorrhea have good pain management. It is expected that parents, schools, and health workers provide knowledge to an adolescent who experiences dysmenorrhea to be able to do pain management.

Lutfiandini, C, T., Kusumaningrum, T., \& Armini, N, K, A. (2020). Pain Selfmanagement in Adolescent with Dysmenorrhea. Pediomaternal Nurs. J., 6(2), 66-73. Doi: http://dx.doi.org/10.20473/pmnj.v6i2.14392

\section{INTRODUCTION}

Every woman has a different menstrual experience. Some menstruate without complaints, and most who experience menstruation with complaints. Complaints that often occur are menstrual pain, which is generally harmless but can interfere with comfort and daily activities (Sari, 2015). Dysmenorrhea causes activity intolerance, severe pain resulting in absence from school, and experiencing difficulty sleeping, and 
feeling restless (Aziato, Dedey and CleggLamptey, 2014). Self-management is the ability of individuals to direct behavior or the ability to do various things despite the many obstacles that must be faced to improve health (G. Kisokanth, 2013).

According to Diane or Clebowy et al. (2013), self-management has factors external and internal. External factors include adherence to self-management, which provides family support, peer groups, and medical teams that can provide knowledge related to the disease. Internal factors include obstacles to self-management, such as low awareness to control oneself, thoughts about failure, and feelings of the feeling of lack of self-control over the illness. Individuals who have compliant self-management involvement can increase self-efficacy (Ryan and Sawin, 2009). Self-efficacy is a belief that is owned by every individual in performing certain behaviors to overcome existing problems. Each person has different selfefficacy depending on the knowledge they have or experiences that have been faced (Alwisol, 2009). The source of knowledge is information, whether the subject is seeking information himself or getting information from others. Teenagers who have good information can determine the right decision making in self-management (Atak, 2007).

Individuals who have compliant selfmanagement involvement can increase selfefficacy (Ryan and Sawin, 2009). Self-efficacy is a belief that is owned by every individual in performing certain behaviors to overcome existing problems. Every person has different self-efficacy depending on the knowledge they have or experiences that have been faced (Alwisol, 2009). Most respondents answered that they did not know the cause of dysmenorrhoea, providing information about the purpose of dysmenorrhea could help make effective treatment choices (Chen et al., no date). Dysmenorrhea can be treated with pharmacological (analgesic drugs, hormonal therapy, and nonsteroid drugs prostaglandin) and non-pharmacological therapy (warm compresses, exercise, and relaxation) (Marlinda, Rosalina and Purwaningsih, 2013).

Data from WHO found 1,769,425 people $(90 \%)$ of women with dysmenorrhoea, 10 $15 \%$ of whom had severe dysmenorrhoea
(Nurwana, Yusuf and Faizal, 2017). Based on data from the National Health and Nutrition Examination Survey (NHANES), the incidence of dysmenorrhoea in adolescents in Indonesia with a prevalence between $43 \%$ to $93 \%, 20-25 \%$ of them experience severe dysmenorrhoea (additional references) (Suliawati, 2013).

Young women consider menstrual pain as something that is considered normal. Lack of knowledge about how to cope with menstrual pain makes teens treat it in an inappropriate way, such as buying drugs without a doctor's prescription (Wong, 2018). The existence of good information support can increase knowledge so that young women who experience dysmenorrhea can have strong self-efficacy and can make decisions in inappropriate pain management selfmanagement (Ryan and Sawin, 2009). The process of self-management requires selfregulation skills to manage chronic conditions or risk factors. Self-management theory focuses on the dimensions of context, processes, and outcomes that affect individuals in the process of selfmanagement so that it can produce more positive things in improving selfmanagement in certain individuals (Ryan and Sawin, 2009). Teenagers who have good selfmanagement are expected to be able to cope with menstrual pain. The study aimed to analyze the self-management of pain in adolescents with dysmenorrhoea.

\section{METHOD}

\subsection{Design}

This research was conducted by a crosssectional design. The cross-sectional study is a research design that emphasizes the time of measuring or observing independent and dependent variable data only once at a time (Nursalam, 2015). In this study, the independent and dependent variables were assessed simultaneously at one time; there was no follow up. With this study, it can be explained that there is a relationship between self-efficacy, decision making, and information support (independent variable) with self-management of pain in adolescent girls with dysmenorrhoea in Public Junior High School IV Lamongan (dependent variable). 


\subsection{Population, Samples, and Sampling}

The population in this study were 7 th and 8th-grade female students of Public Junior High School IV Lamongan who had dysmenorrhoea. The sample in this study were some female students of Public Junior High School IV Lamongan by establishing inclusion and exclusion criteria. The inclusion criteria are adolescent have experienced dysmenorrhea. The Exclusion Criteria for this study were not in place due to illness. The sampling technique used in this research is random probability type simple random sampling. The number of respondents in this study was 129 respondents who fit the inclusion and exclusion criteria. In this study, there are two variables, namely the independent variable and the dependent variable. Independent variables are usually manipulated, observed, and measured to determine the relationship or influence on other variables (Nursalam, 2017).

\subsection{Variables}

The independent variables in this study were self-efficacy, decision making, and information support. The dependent variable or dependent variable is a variable whose value is determined by other variables (Nursalam, 2017). The dependent variable in this study is the self-management of pain in adolescents who experience dysmenorrhoea.

\subsection{Instruments}

The instrument used in this study was a questionnaire consisting of demographic data, self-efficacy, decision making, information support, and self-management of pain. The demographic data questionnaire consisted of current age, menarche age, menstrual length, menstrual cycle length, family history, complaints during dysmenorrhea, and medications taken during dysmenorrhea. The self-efficacy questionnaire consisted of 10 questions with three parameters, namely the ability to act, the experience of the closest people, and mood. The decision-making questionnaire consists of 10 questions with two settings, namely individual coping in problem-solving and problem-solving plans. The information support questionnaire consisted of 8 questions with two parameters, namely health information and social support. The pain self-management cell questionnaire consisted of 10 subjects with three parameters, namely the use of pharmacological therapy, the use of nonpharmacological therapy, self-management. The instrument of self-efficacy, decision making, and information support is taken from the parameters in the research conducted by Windi (2016) about "selfefficacy of the woman to prevent breast cancer" and modified again by study following predetermined parameters. Instrument pain self-management was taken from the questionnaire by Mohamed $\mathrm{M}$. (2016) about "epidemiology of dysmenorrhea among secondary-school students in Northern Saudi Arabia" and modified again by research following predetermined parameters. The instrument used in this stud was tested for validity and reliability on April 26, 2019 with totaly of 20 respondents at Junior School 2 Lamongan.

\subsection{Procedure}

The data collection procedure starts with the researcher explaining the purpose of the study and coordinating the time of the research to be carried out by the researcher. The study was conducted by being in class after school. How to select respondents by introducing, explaining the purpose of the study, and conveying research inclusion criteria to each class. Respondents who do not fit the requirements can leave the room. Next, the researcher explains how to fill out the questionnaire, the benefits of the study, the right of resignation, research ethics, and information sources that can be contacted. Researchers provide informed consent for prospective female respondents. Prospective student students are given the right to refuse or are willing to be the subject of research that has been signed by a parent or guardian. The next day the researcher goes to classes to collect the consent form, and students who are willing to become respondents are given a questionnaire by the researcher. The researcher assists the respondent directly in filling out the questionnaire so that if there are unclear questions, the respondent can ask the researcher directly. There were five questionnaires given to female respondents, 
Table 1. Characteristics of Respondents for pain self-management in adolescent girls with Dysmenorrhea $(\mathrm{n}=129)$

\begin{tabular}{lccc}
\hline Characteristics & Criteria & n & \% \\
\hline Age (year) & 12 & 29 & 22.5 \\
& 13 & 55 & 42.6 \\
& 14 & 41 & 31.8 \\
Menarche age (year) & 15 & 5 & 3.1 \\
& $\leq 12$ & 76 & 24.0 \\
Duration of menstruation (day) & $>13$ & 9.3 & 67.4 \\
& $<6$ & 31 & 23.3 \\
Period of menstrual cycle (day) & 7 & 6.2 \\
& $>8$ & 91.5 \\
Family history & $<20$ & 2.3 \\
Complains of dysmenorea & $21-34$ & 30 & 51.9 \\
& $>35$ & 118 & 48.1 \\
& Yes & 3 & 3.9 \\
Use of medication & No & 67 & 9.3 \\
& Nausea & 62 & 5 \\
& Dizzy & 12 & 86 \\
\hline
\end{tabular}

namely the demographic data questionnaire, self-efficacy, decision making, information support, and pain self-management. The type of data collected is primary data, i.e., data obtained by researchers directly from respondents.

\subsection{Analysis}

Analysis of the data used is the Spearman Rank Correlation statistical test with a significance level designed $\alpha<0.05$. If the $\alpha \leq$ 0.05 test results, then $\mathrm{H} 1$ is accepted, meaning that there is a meaningful relationship that is, the higher the predisposing factors that young women have, the higher the pain self-management. If $\alpha \geq$ $0.05, \mathrm{H} 0$ is accepted, meaning that there is no meaningful relationship between the measured variables. All statistical data measurements were performed using computer software, SPSS.

\subsection{Ethical Clearance}

This research was conducted following research ethics in which researchers requested permission from related parties before the study began procedures related to research ethics, including approval letters, anonymity, confidentiality, fairness, the principle of honesty (veracity), and the principle of keeping promises (fidelity). This research has conducted an ethics test at the Airlangga University Faculty of Nursing Faculty of Health Research Ethics Commission with the number: 1378-KEPK on April 30, 2019.

\section{RESULT}

Based on the results of the characteristics of respondents showed that from age, the majority of respondents aged 13 years as much as 55 respondents (42.6\%). The majority of the age of first menstruation experienced by respondents $\leq 12$ years were 98 people $(76 \%)$. The period of menstruation experienced by respondents is seven menstrual days as many as 87 respondents (67.4\%). The majority of menstrual cycles experienced by respondents are 21-34 days as many as 118 respondents (91.5\%). A family history of dysmenorrhea mostly has families who experience dysmenorrhea with 67 respondents (51.9\%). Complaints felt during dysmenorrhea mostly experienced complaints of lower abdominal pain as many as 111 respondents (86\%). The drugs used by respondents to reduce the pain of dysmenorrhea were mostly 113 respondents who did not take any medication (87.6\%) (Table 1).

In the self-efficacy questionnaire, most respondents had High self-efficacy as many 
Table 2. Relationship between self-efficacy and pain self-management in young women who experience dysmenorrhea $(n=129)$

\begin{tabular}{|c|c|c|c|c|c|c|}
\hline \multirow{3}{*}{ Self-efficacy } & \multicolumn{4}{|c|}{ Pain Self-management } & \multirow{2}{*}{\multicolumn{2}{|c|}{ Total }} \\
\hline & \multicolumn{2}{|c|}{ Enough } & \multicolumn{2}{|c|}{ Good } & & \\
\hline & $\mathbf{n}$ & $\%$ & $\mathbf{n}$ & $\%$ & $\mathbf{n}$ & $\%$ \\
\hline Low & 8 & 6.2 & 0 & 0 & 9 & 6.2 \\
\hline Moderate & 56 & 43.4 & 2 & 1.6 & 58 & 45 \\
\hline High & 50 & 38.8 & 13 & 10.1 & 63 & 48.8 \\
\hline \multirow[t]{2}{*}{ Total } & 114 & 88.4 & 15 & 11.6 & 129 & 100 \\
\hline & \multicolumn{4}{|c|}{$p=0.004 r=0.24$} & & \\
\hline
\end{tabular}

Table 3. Relationship between Decision Making and self-management of pain in young women who experience dysmenorrhea $(n=129)$

\begin{tabular}{|c|c|c|c|c|c|c|}
\hline \multirow{3}{*}{ Decision Making } & \multicolumn{4}{|c|}{ Pain Self-management } & \multirow{2}{*}{\multicolumn{2}{|c|}{ Totally }} \\
\hline & \multicolumn{2}{|c|}{ Enough } & \multicolumn{2}{|c|}{ Good } & & \\
\hline & $\mathbf{n}$ & $\%$ & $\mathbf{n}$ & $\%$ & $\mathbf{n}$ & $\%$ \\
\hline Low & 1 & 0.8 & 0 & 0 & 1 & 0.8 \\
\hline Enough & 53 & 41.1 & 1 & 0.8 & 54 & 41.9 \\
\hline Good & 60 & 46.5 & 14 & 10.9 & 74 & 57.4 \\
\hline Total & 114 & 88.4 & 15 & 11.6 & 129 & 100 \\
\hline \multicolumn{7}{|c|}{$\mathrm{p}=0.003 \mathrm{r}==0.26$} \\
\hline
\end{tabular}

Table 4. Relationship between Information Support and pain self-management in young women who experience dysmenorrhea $(n=129)$

\begin{tabular}{|c|c|c|c|c|c|c|}
\hline \multirow{3}{*}{ Information Support } & \multicolumn{4}{|c|}{ Pain Self-management } & \multirow{2}{*}{\multicolumn{2}{|c|}{ Totally }} \\
\hline & \multicolumn{2}{|c|}{ Enough } & \multicolumn{2}{|c|}{ Good } & & \\
\hline & $\mathbf{n}$ & $\%$ & $\mathbf{n}$ & $\%$ & $\mathbf{n}$ & $\%$ \\
\hline Low & 2 & 1.6 & 0 & 0 & 2 & 1.6 \\
\hline Enough & 103 & 79.8 & 10 & 7.8 & 113 & 87.5 \\
\hline Good & 9 & 7.0 & 5 & 3.9 & 14 & 10.9 \\
\hline Total & 114 & 88.4 & 15 & 11.6 & 129 & 100 \\
\hline \multicolumn{7}{|c|}{$\mathrm{p}=0.003 \mathrm{r}==0.26$} \\
\hline
\end{tabular}

as 63 respondents $(48.8 \%)$. This shows that most respondents can act High, have confidence in telling menstrual pain experienced by others who are High, and always think positively of themselves despite feeling pain during menstruation. Statistical test results between self-efficacy and pain self-management in adolescent girls experiencing dysmenorrhea with Spearman Rho showed $\mathrm{p}=0.004$ and $\mathrm{r}=0.24$, which means that there is a relationship with the weak correlation coefficient. The results of this study indicate that the majority of respondents have moderate self-efficacy with sufficient pain self-management as many as 56 respondents (43.4\%) (Table 2 ).

Statistical test results between decision making and pain self-management in young women who experience dysmenorrhea with Spearman Rho show $p=0.003$ and $r=0.26$, which means that there is a relationship with the correlation coefficient value sufficient.
The results of this study indicate that the majority of respondents have good decision making with self pain management as much as 60 respondents $(46.5 \%)$ (Table 3 ).

Statistical test results between information support and self-management of pain in adolescent girls experiencing dysmenorrhea with Spearman Rho showed $\mathrm{p}$ $=0.003$, and $r=0.26$, which means that there is a relationship with the correlation coefficient value is sufficient. The results of this study indicate that the majority of respondents have sufficient information support with sufficient pain self-management as many as 103 respondents (79.8\%) (Table 4).

\section{DISCUSSION}

There was a relationship between selfefficacy and self-management of pain in adolescent girls experiencing dysmenorrhea with weak correlation coefficient values. The 
correlation coefficient is positive, meaning that if self-efficacy is high, then good menstrual pain self-management. Respondents in this study aged $12-15$ years so that anxiety will increase where hormonal changes occur that cause discomfort, anxiety, stress on adolescents, and decreased selfefficacy in adolescents when doing menstrual pain self-management. In line with research that says self-efficacy is an individual's trust that is owned to show a behavior (Pajares, 2010). The higher the person's awareness of their abilities, the easier they will deal with the problem at hand. Emotional conditions, such as anxiety, stress, and negative mood, affect the failure or success of the results.

Self-efficacy can change a person's behavior with the strength and confidence in an expectation that someone can deal with positive behavior (Yücel, Kendirci and Gül, 2018). This can be applied to conditions such as experiencing dysmenorrhea experienced by adolescents, which shows that adolescent self-efficacy is a mediator to improve the quality of self-management of pain for themselves optimally to improve the quality of life. There is a significant relationship between the pain and mental status of adolescents so that they have good selfefficacy (Sewvandi et al., 2018). The importance of health problems in adolescents who experience menstrual pain is related to the mental status of adolescents so that they have good self-efficacy in dealing with menstrual pain.

This study shows that most respondents have moderate self-efficacy and selfmanagement of menstrual pain. Most respondents still have moderate self-efficacy because they still often cope with menstrual pain by ignoring it, but there are still respondents who receive menstrual pain. Most respondents have sufficient selfmanagement due to the lack of respondents who use non-pharmacological management, but there are still respondents who dare to discuss menstrual pain with those closest to them frequently.

There was a relationship between decision making and self-management of pain in adolescent girls who experience dysmenorrhea with a sufficient correlation coefficient. The correlation coefficient is positive, which means good decision making will be followed by good menstrual pain selfmanagement.

Decision making is influenced by several factors, such as personal, social, and psychological factors (Kotler, 2018). Other research also shows that some female students know about menstrual pain care, but they do not take medication because it is considered normal, can still tolerate pain and high medical costs (Chiu et al., 2017). This is in line with research conducted by (Pajares, 2010) that the health centre plays an essential role in this matter, all mothers and daughters must be given enough information about menstruation and know the condition should be referred to a doctor, so they can have the ability to make good decisions and right.

Lack of information due to lack of knowledge and experience of young women so that they are not ready to solve menstrual pain problems. Teenagers who have high knowledge can make good decisions and appropriate pain management when experiencing dysmenorrhea. Students know to make decisions in dealing with menstrual pain with Complementary and Alternative Medicine Methods (CAM) such as hot compresses, massage, drinking herbal tea, diet, nutritional supplements, and exercise (Midilli, Yasar and Baysal, 2015).

Most respondents have good decision making and self-management of menstrual pain. Most respondents still have good decision making because they have never blamed destiny when they cannot make decisions in dealing with menstrual pain and make plans in dealing with menstrual pain and follow the plan. Most respondents already have sufficient self-management due to the lack of respondents who use nonpharmacological management such as warm compresses, and most of the respondents dare to discuss menstrual pain with those closest to them frequently.

There was a relationship between information support and pain selfmanagement in adolescent girls who experience dysmenorrhea with a sufficient correlation coefficient value. The correlation coefficient is positive, which means that if the information support is good, it will have a good menstrual pain self-management. 
Most of the respondents shared their experience of menstrual pain to those closest to them so that suggestions for menstrual pain treatment were given. Adolescents need information support in increasing knowledge. Good knowledge about dysmenorrhea can help someone to manage when experiencing the disorder. Information support is not only obtained from counseling activities but can be from the initiative of respondents in finding various information about menstrual pain. This is in line with research, which states that most participants respond that they do not know the cause of dysmenorrhoea, providing information about the cause of dysmenorrhea can help make effective treatment choices (Chen et al., 2016). Inadequate education provided to respondents due to lack of knowledge about the physiology of menstruation which results in low levels of medical consultation, girls do not know the drugs they use which proves that girls are lacking knowledge of selfmedication and cause harm to health because the drugs used are not appropriate (Wong, 2018).

Most respondents have sufficient information support and self-management of menstrual pain. Most respondents still have enough decision making because they have never been to a health facility when experiencing menstrual pain, and most respondents have the initiative to seek information about managing menstrual pain frequently. Most of the respondents already have sufficient information and selfmanagement support because in the neighborhood where the respondent has never done health education, and most of the respondents dare to discuss menstrual pain with those closest to them frequently.

\section{CONCLUSION}

Adolescent girls with complaints of dysmenorrhea mostly have adequate pain management, even though there is a small number who are already good. Teenagers will have pain management for good dysmenorrhea if it is supported by positive self-efficacy factors, good decision making, and adequate information support. Further research needs to be done on the mental readiness of adolescent girls to deal with menstrual complaints based on sociodemographic factors.

\section{ACKNOWLEDGEMENT}

Our praise and gratitude to Allah SWT's presence, thanks to His grace and guidance, we were able to complete this research. Hereby, let me express my sincere thanks to the Principal of Public Junior High School IV Lamongan and to all respondents who have helped in making this research complete.

\section{CONFLICT OF INTEREST}

The authors declare that there is no conflict of interest.

\section{REFERENCES}

Alwisol (2009) Psikologi Kepribadian. Malang: UMM Press.

Atak, N (2007) The Effect of Education on Knowledge, Self-management Behaviors and Self Efficacy of Patient with Type 2 Diabetes. Australian Journal of Asvanced Nursing. Vol 2 Number. 2.

Aziato, L., Dedey, F. and Clegg-Lamptey, J. (2014) 'The experience of dysmenorrhoea among Ghanaian senior high and university students: pain characteristics and effects', Reproductive Health.

Chen, C. et al. (2016) 'Beliefs About Dysmenorrhea and Their Relationship to Self-Management'.

Chlebowy, Diane orr et al. (2009) Gender Differences in Diabetes Selfmanagement Among African American Adults DOI. 10.1177/0193945912473370.

Chiu, M. et al. (2017) 'Influencing factors of dysmenorrhoea among hospital nurses : a questionnaire survey in Taiwan'.

G, Kisokanth. (2013) 'Factors Influencing Self-management of Diabetes Mellitus: a Review Article', Sri Lanka: Eastern University \& the University of Sri Jayewerdenepura.

Kotler, P. (2018) Prinsip - Prinsip Pemasaran Manajemen. Jakarta: Prenhalindo.

Marlinda, R., Rosalina and Purwaningsih, P. 
(2013) 'Pengaruh senam terhadap penurunan dismenore pada remaja putri di desa sidoharjo kecamatan pati', Jurnal Keperawatan Maternitas, 1(2), pp. 118123.

Midilli, T. S., Yasar, E. and Baysal, E. (2015) 'Dysmenorrhea Characteristics of Female Students of Health School and Affecting Factors and Their Knowledge and Use of Complementary and Alternative Medicine', pp. 194-204.

Nursalam (2015) Metodologi Penelitian Ilmu Keperawatan: Pendekatan Praktis. 4th edn. Edited by P. P. Suslia, A and E. Lestari. Jakarta: Salemba Medika.

Nursalam (2017) Metodologi Penelitian Ilmu Keperawatan. 4th edn. Jakarta: Salemba Medika.

Nurwana, Yusuf, S. and Faizal (2017) 'Analisis Faktor yang Berhubungandengan Kejadian dismenore pada Remaja Putri di SMA Negeri 8 Kendari year 2016', p. 250-731X.

Pajares, F. (2010) 'Self efficacy beliefs' DOI. 10.1016/B978-0-08-044894-7.00620-5.
Ryan, P. and Sawin, K. (2009) 'The Individual and Family Self-Management Theory: Background and perspectives on context, process, and outcomes'.

Sari, D. (2015) 'Hubungan Stres dengan Kejadian Dismenore Primer pada Mahasiswi Pendidikan Dokter Fakultas Kedokteran Universitas Andalas', 4(2).

Sewvandi, H. et al. (2018) Knowledge and attitudes towards dysmenorrhea among adolescent girls in an urban school in Sri Lanka', pp. 58-64.

Suliawati, G. (2013) 'Hubungan Umur, Paritas Dan Status Gizi Dengan Kejadian Dismenore Pada Wanita Usia Subur Di Gampong Baitussalam Aceh Besar', Skripsi STIKes U'budiyah Banda Aceh.

Wong, C. (2018) 'Health-related quality of life among Chinese adolescent girls with Dysmenorrhoea', pp. 1-10.

Yücel, G., Kendirci, M. and Gül, Ü. (2018) 'Menstrual Characteristics and Related Problems in 9- to 18-Year-Old Turkish School Girls', J Pediatr Adolesc Gynecol, 31(4), pp. 350-5. 